\title{
A major positive regulatory region located far upstream of the human $\alpha$-globin gene locus
}

\author{
D.R. Higgs, W.G. Wood, A.P. Jarman, J. Sharpe, J. Lida', I.-M. Pretorius, and H. Ayyub \\ Medical Research Council Molecular Haematology Unit, Institute of Molecular Medicine, John Radcliffe Hospital, \\ Headington, Oxford OX3 9DU UK, ' ${ }^{1}$ Royal Veterinary College, Royal College Street, London NW1 0TU UK
}

\begin{abstract}
We have identified a remote, tissue-specific, positive regulatory element that is of major importance in determining the level of human $\alpha$-globin gene expression. Stable transformants containing this DNA segment linked to the $\alpha$ gene in mouse erythroleukemia cells expressed human $\alpha$ mRNA at levels that are indistinguishable from those seen in interspecific hybrids containing the human $\alpha$ genes in their normal context on chromosome 16. Furthermore, all transgenic mice containing the $\alpha$ genes linked to this region expressed $\alpha$-globin mRNA at high levels in erythroid tissues; and in one such mouse, readily detectable levels of human $\alpha$-globin chains could be demonstrated in the peripheral blood. There is considerable similarity in the position, structure, and function of this region upstream of the $\alpha$-globin complex with previously described elements within the $\beta$-globin dominant control region (DCR). This is in marked contrast to other structural and functional differences between the two gene clusters. It seems likely that these critical, positive regulatory regions might provide target sequences through which coordinate regulation of the $\alpha$-and $\beta$-like globin genes is achieved.
\end{abstract}

[Key Words: $\alpha$-Globin; regulatory region; gene expression]

Received May 2, 1990; revised version accepted June 21, 1990.

The human $\alpha$ - and $\beta$-globin gene families are derived from a common ancestral gene. The $\alpha$-globin cluster consists of three functional genes, arranged $5^{\prime}-\zeta 2-\alpha 2-\alpha 1-$ $3^{\prime}$, near the tip of chromosome $16 \mathrm{p}$. The $\beta$ gene cluster includes five functional genes, arranged $5^{\prime}-\epsilon^{-}{ }^{-} \gamma_{-}{ }^{A} \gamma-\delta-\beta$ $3^{\prime}$, within the terminal band of chromosome $11 \mathrm{p}$. These genes are regulated in a strictly tissue- and stage-specific manner to produce embryonic $\left(\zeta_{2} \epsilon_{2}, \alpha_{2} \epsilon_{2}\right.$, and $\left.\zeta_{2} \gamma_{2}\right)$, fetal $\left.\mid \alpha_{2} \gamma_{2}\right)$, and adult $\left(\alpha_{2} \delta_{2} ; \alpha_{2} \beta_{2}\right)$ hemoglobins (for review, see Karlsson and Nienhuis 1985; Higgs et al. 1989). This finely balanced pattern of expression of two physically separated loci provides an interesting example of the coordinate regulation of genes encoding heterodimeric proteins.

The mechanism by which coordinate expression is achieved is unknown. Comparisons of the structure of the $\alpha$ - and $\beta$-like genes have revealed remarkable differences between them. The $\beta$-globin genes appear to be similar to many other tissue-specific genes in their structure (Efstratiadis et al. 1980), methylation profile (van der Ploeg and Flavell 1980), and pattern of replication timing (Holmquist 1987; Epner et al. 1988). In contrast, the $\alpha$ genes are less typical in that they have an unusually high GC content $(>60 \%)$, are associated with unmethylated CpG-rich islands (Bird et al. 1987; Fischel-Ghodsian et al. 1987a,b), and replicate early in all cell types (Holmquist 1987). Similarly, the higher order structures of the two gene clusters are quite different; whereas nuclear matrix-associated regions can be demonstrated within and around the $\beta$-globin complex, no such attachment sites have been identified within 180 $\mathrm{kb}$ around the $\alpha$ complex (Jarman and Higgs 1988), in keeping with other GC-rich regions of the genome (Beggs and Migeon 1989).

These differences also extend to the expression of the $\alpha$ - and $\beta$-like genes in a variety of experimental systems. In transient systems, $\alpha$-globin genes are expressed $\sim 100$ fold more efficiently than $\beta$ genes in parallel assays (Mellon et al. 1981; Humphries et al. 1982; Treisman et al. 1983). Similarly, in stable transformants of mouse erythroleukemia cells (MELCs), $\alpha$ genes are expressed constitutively at a level that the $\beta$ genes achieve only after induction of terminal differentiation (Charnay et al. 1984). In transgenic mice the $\beta$-globin gene is expressed in a tissue-specific manner (Magram et al. 1985; Townes et al. 1985; Kollias et al. 1986), whereas the $\alpha$ genes are not expressed from any segments of the $\alpha$ cluster that have been analyzed thus far (Palmiter and Brinster 1986; Hanscombe et al. 1989; Ryan et al. 1989a).

In all of these experimental systems, the level of globin gene expression is considerably less (often $<1 \%$ ) than that seen from the endogenous genes in erythroid cells. Furthermore, the levels of expression are depen- 
dent on the site of integration in the genome. However, $\alpha$ and $\beta$ genes on intact chromosomes 16 and 11 transferred to interspecific human $\times$ MELC hybrids can be induced to express at a level approximating that of the endogenous mouse globin genes (Deisseroth and Hendrick 1979; Zeitlin and Weatherall 1983; Papayannopoulou et al. 1986). The implication of these observations is that additional cis-regulatory sequences, remote from the structural genes, are required to produce high levels of expression that are independent of the position of integration in the genome. Grosveld et al. (1987) have demonstrated that such positive regulatory sequences, [collectively referred to as the dominant control region (DCR) or locus activating region (LAR)], are present $5-20 \mathrm{~kb}$ upstream of the human $\beta$-globin cluster. Furthermore, the DCR interacts with heterologous promoters, including that of the $\alpha$-globin gene, to produce high levels of erythroid-specific expression in both MELCs and transgenic mice (Blom van Assendelft et al. 1989; Ryan et al. 1989a; Talbot et al. 1989). These observations have now been confirmed and extended in a number of independent studies (Behringer et al. 1989; Curtin et al. 1989; Enver et al. 1989; Forrester et al. 1989; Greaves et al. 1990; Hanscombe et al. 1989; Ryan et al. 1989b; Tuan et al. 1989; Collis et al. 1990).

From the apparent differences between the globin gene clusters, it is not clear whether the high levels of $\alpha$ globin gene expression observed in vivo are determined by similar discrete positive regulatory sequences or alternative control mechanisms. Nevertheless, the recent identification of a naturally occurring deletion of sequences upstream of the $\alpha$ complex that down-regulates both $\alpha$ genes [referred to as chromosome $(\alpha \alpha)^{\text {RA }}$ ] supports the notion that remote positive regulatory sequences also exist upstream of this cluster (Hatton et al. 1990). To identify these putative sequences, we have constructed recombinants containing an $\alpha$-globin gene linked to fragments normally contained within the $62-\mathrm{kb}$ segment deleted from the $\langle\alpha \alpha\}^{\mathrm{RA}}$ chromosome and analyzed their expression in MELCs and transgenic mice. We have demonstrated that remote positive regulatory sequences bearing similarities to elements within the $\beta$-globin cluster are present $30-50 \mathrm{~kb}$ upstream of the $\alpha$-globin genes. The critical positive regulatory sequences contained in these regions provide cis-acting target sites through which coordinate regulation of the gene clusters might be achieved.

\section{Results}

The MELC line provides a suitable system for identifying positive regulatory sequences

The search for positive regulatory sequences within the region of interest defined by the naturally occurring variants (see Fig. 1 and legend) required a relatively rapid assay system that is capable of sustaining a high level of expression of the $\alpha$-globin genes. MELC is an immortalized adult cell line blocked in erythroid differentiation prior to globin gene expression. Upon induction with various polar chemicals, terminal differentiation pro- ceeds during which the endogenous $\alpha, \beta^{\text {major- }}$, and

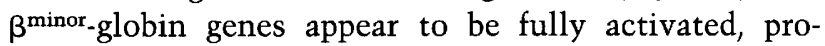
ducing up to $20 \mathrm{pg}$ of hemoglobin per cell (for review, see Marks et al. 1987). Similarly, interspecific MELC hybrids containing human chromosome 16 , maintained by selection for the human APRT locus, express the human $\alpha$ genes (but not the embryonic $\zeta$ gene) at high levels (Deisseroth and Hendrick 1979; Zeitlin and Weatherall 1983; Charnay et al. 1984; Anagnou et al. 1985) when induced.

To provide a standard by which to judge the level of expression of artificial constructs containing the $\alpha$ genes, we analyzed the expression of these genes in 11 interspecific hybrids containing human chromosome 16 (Table 1; Fig. 2) after induction with dimethyl sulfoxide (DMSO) or hexamethylene-bis-acetamide (HMBA). Despite continuous selection, some hybrids contained an average of less than one copy of human chromosome 16 per cell, as determined by quantitative DNA analysis. Correcting for this, the levels of human $\alpha$ mRNA were $\sim 55 \%$ of the endogenous mouse $\alpha$ mRNA. Similarly, the proportion of human $\alpha$-globin synthesis represents $\sim 40 \%$ of mouse $\alpha$-globin synthesis per gene copy. A hybrid containing the abnormal $(\alpha \alpha)^{\text {RA }}$ chromosome (Fig. 1) did not produce detectable levels of human $\alpha$-globin synthesis following induction (Hatton et al. 1990). Thus, although the human $\alpha$ genes are not expressed quite as efficiently as the mouse $\alpha$ genes, the MELC line provides a suitable system for identifying putative positive regulatory sequences located upstream of the $\alpha$-globin cluster.

A positive regulatory sequence is present upstream of the a-globin genes

To analyze the upstream region between coordinates 0 and -52 , small $(\sim 5-12 \mathrm{~kb})$ BamHI, BglII, or BamHI$B g I I I$ fragments were cloned in both orientations into the BamHI site of the vector pNXKN $\alpha 23$ /see Materials and methods; Fig. 3), which contains the human $\alpha 2-$ globin gene. Each recombinant fragment could then be released and purified from the vector following digestion with NotI. In this way, a set of nonoverlapping recombinant fragments was produced, together representing $-90 \%$ of the upstream region linked to the $\alpha$-globin gene. Two small areas $(-33$ to -37 and -47 to -48$)$ were not included in this initial screening procedure. The levels and patterns of expression of these constructs were also compared with a construct containing an active region of the $\beta$-globin DCR (hypersensitive sites II and III; Grosveld et al. 1987) attached to an $\alpha$-globin gene (see Materials and methods).

Each fragment was cotransfected with a 7.8-kb DNA fragment containing the hamster APRT gene into an APRT-deficient MELC line (585, a gift from Dr. A. Deisseroth). For each experiment, 10-25 pools of stable transformants $\left(\mathrm{APRT}^{+}\right.$), each containing an average of $5-15$ individual clones (range 1-190), were induced into terminal differentiation with HMBA and analyzed by 
Figure 1. (Top) The $\alpha$-globin gene cluster and flanking DNA, indicating the position of the functional genes (solid square) and pseudogenes (hatched square). Position 0 represents the $\zeta$ mRNA cap site. At present, the functional status of the $\theta 1$ gene is undetermined. (Bottom) Black bars indicate the extent of dele-

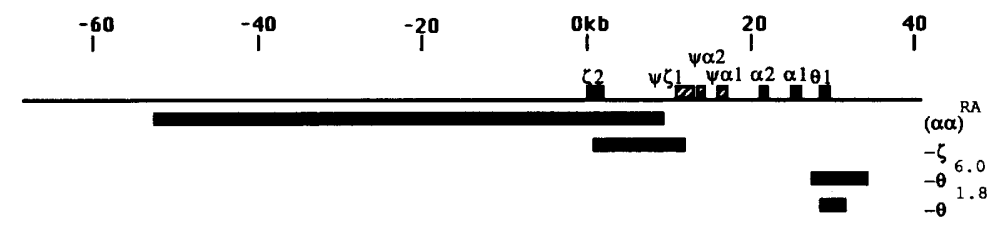
tions associated with the $(\alpha \alpha)^{\text {RA }}$ (Nicholls et al. 1987), $-\zeta$ (Winichagoon et al. 1982), $-\theta^{6.0}$ and $-\theta^{1.8}$ (Fei et al. 1988) chromosomes. Although the $(\alpha \alpha)^{\mathrm{RA}}$ deletion gives rise to $\alpha$ thalassemia, the $-\zeta,-\theta^{6.0}$, and $-\theta^{1.8}$ mutations produce no discernible alteration in phenotype (for review, see Higgs et al. 1989).

comparing the levels of human $\alpha$ mRNA in each pool to that present in $5 \mu \mathrm{g}$ of RNA from the cell line K562. We estimated that this standard contains $\sim 1 \%$ of the amount of human $\alpha$ mRNA that would be present in an equivalent amount of total RNA from terminally differentiated erythroblasts or MELCs. Pools with detectable amounts of human $\alpha$-globin mRNA were analyzed further by comparing the relative levels of human and mouse $\alpha$-globin mRNA and obtaining estimates of the average gene copy number per cell (Fig. 4). In addition, we compared the levels of $\alpha$ mRNA before and after induction; and in a small number of experiments, the level of human $\alpha$-globin chain synthesis was measured.

All 11 pools of stable transformants containing the $\beta$ globin DCR construct expressed human $\alpha$-globin mRNA at levels greater than the K562 standard. We estimated that these levels were between 4 and $100 \%$ of the endogenous mouse $\alpha$ mRNA per gene copy. These results demonstrate that MELCs are capable of sustaining high levels of $\alpha$ mRNA production from transfected constructs, as well as from the intact copy of human chromosome 16.

Stable transformants containing either the $\alpha$-globin genes alone (fragments 1-4, Fig. 3) or the entire region spanning the $\zeta$ and $\alpha$ genes (fragment 13, Fig. 3) expressed $\alpha$ mRNA at a low level (less than the K562 standard and $<1 \%$ of the endogenous mouse $\alpha$ gene). Similar results were obtained whether pools or clones were ana- lyzed; and in two clones selected for their relatively high levels of human $\alpha$ mRNA, no human $\alpha$-globin chain synthesis could be detected (data not shown). This confirms and extends a previous study (Charnay et al. 1984) in which low levels of human $\alpha$-globin expression in MEL stable transformants were also noted. Interestingly, in that study, induction of MELCs had little or no effect on the levels of human $\alpha$ mRNA expression. In contrast, in this series of experiments, we found that the ratio of human to mouse $\alpha$ mRNA in 8 out of 15 pools tested appeared to decrease following induction.

Six of the seven recombinant fragments containing segments from the upstream region linked to the $\alpha 2$ gene (constructs 5-9 and 12, Fig. 3) behaved as the $\alpha$ genes alone, with levels of mRNA either undetectable or considerably less than the endogenous mouse $\alpha$ mRNA (Table 2; Fig. 4). The exception to this pattern was observed in cells transfected with the fragment from recombinant 10 (Fig. 3). The BglII fragment in this recombinant, spanning from coordinate -37 to -47 , consistently supported high levels of $\alpha$-globin mRNA expression (Table 2; Fig. 4). On a per copy basis, expression was at least 50 -fold greater than that seen with any of the other constructs. Constructs containing the same BglII fragment in reverse orientation with respect to the $\alpha 2$ gene (construct 11, Fig. 3) produced similarly high levels of human $\alpha$-globin expression (Table 2; Fig. 4). Furthermore, this expression was inducible in seven of

Table 1. Expression of the a genes in interspecific $M E L \times$ human chromosome 16 hybrids

\begin{tabular}{|c|c|c|c|c|c|}
\hline Hybrid & $\begin{array}{l}\text { Gene copy } \\
\text { number }\end{array}$ & $\begin{array}{l}\alpha \mathrm{h} / \alpha \mathrm{m} \\
\text { mRNA }\{\% \mid\end{array}$ & $\begin{array}{l}\text { Percent } \alpha \mathrm{h} / \alpha \mathrm{m} \\
\text { Globin synthesis } \\
\text { (no. of observations) }\end{array}$ & $\begin{array}{l}\alpha \mathrm{h} / \alpha \mathrm{m} \text { mRNA/ } \\
\text { gene copy }(\%)\end{array}$ & $\begin{array}{l}\alpha \mathrm{h} / \alpha \mathrm{m} \\
\text { globin synthesis/ } \\
\text { gene copy }(\%)\end{array}$ \\
\hline JWH2C-4 & $1-2$ & 15 & $13(1)$ & $30-60$ & $13-26$ \\
\hline JWH2C-6 & $1-2$ & 20 & NS & $40-80$ & NS \\
\hline JWH2C-8 & $1-2$ & 32 & $10(1)$ & $64-120$ & $10-20$ \\
\hline NBuHlA I & 2 & 31 & $14(1)$ & $31-64$ & $14-28$ \\
\hline PSHHIM I & 2 & 20 & $21(1)$ & $20-40$ & $21-42$ \\
\hline $3 \mathrm{~A} 6$ & $\sim 2^{\mathrm{a}}$ & NS & $15-30(7)$ & NS & $30-60$ \\
\hline $8 \mathrm{~B} 6$ & $\sim 2^{a}$ & NS & $3-12(9)$ & NS & $6-24$ \\
\hline $8 \mathrm{E} 4$ & $\sim 2^{a}$ & NS & $15-20(5)$ & NS & $30-40$ \\
\hline $7 \mathrm{Al}$ & $\sim 2^{a}$ & NS & $16-22(3)$ & NS & $32-44$ \\
\hline $2 \mathrm{~A} 2$ & $\sim 2^{\mathrm{a}}$ & NS & 28 & NS & 56 \\
\hline MEL/K562 I & $\sim 2^{\mathrm{a}}$ & NS & $18-20|3|$ & NS & $36-40$ \\
\hline mean & $\sim 2$ & 23 & 16 & 55 & 41 \\
\hline
\end{tabular}

NS indicates not studied; $\alpha$ indicates human $\alpha ; \alpha \mathrm{m}$ indicates mouse $\alpha$.

aThis estimate is based on the observation that most hybrids that were examined cytogenetically by light microscopy appeared to contain only one human chromosome. 


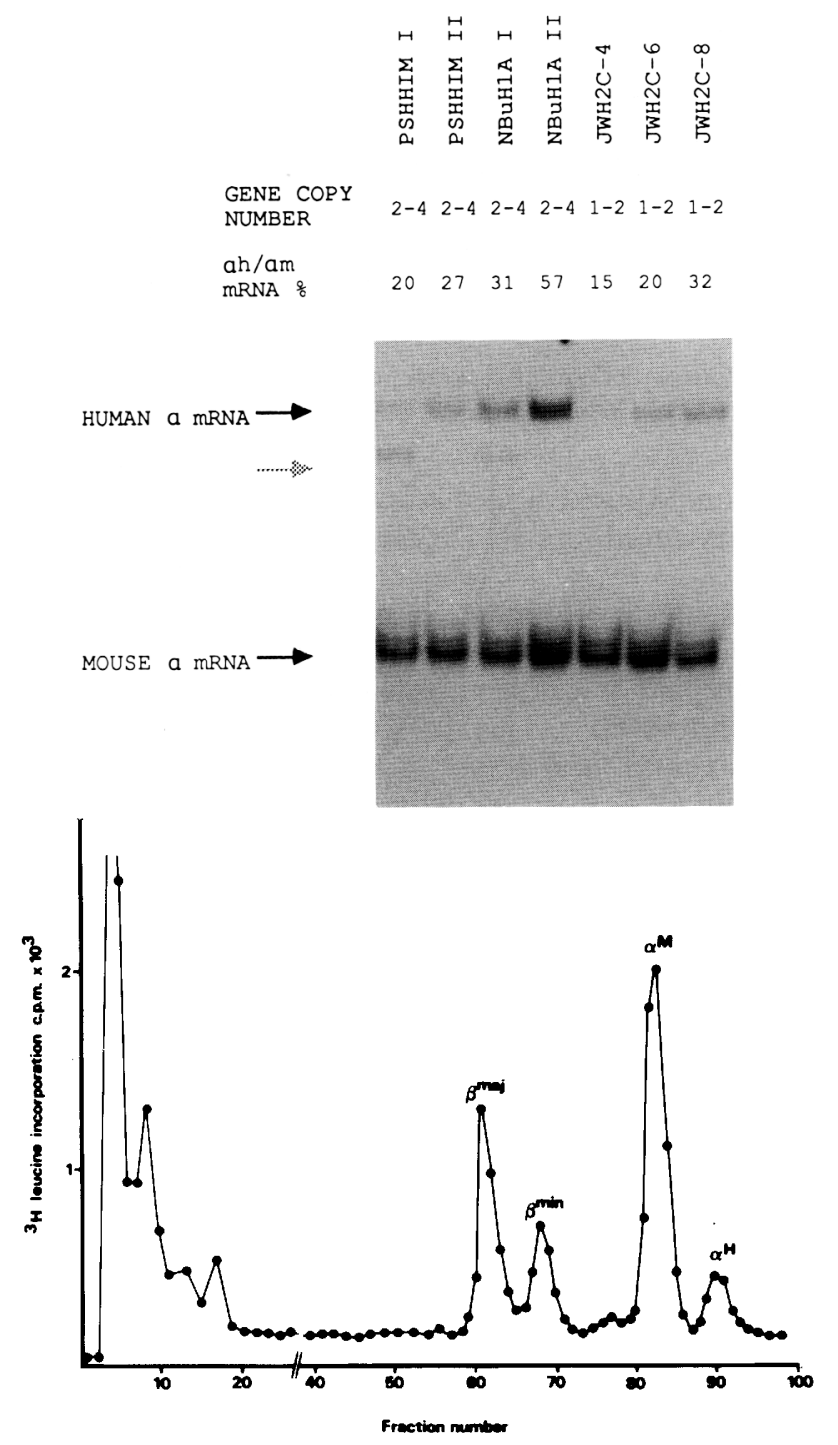

Figure 2. (Top) Autoradiograph of a nuclease protection assay using $0.2 \mu \mathrm{g}$ of RNA from five interspecific hybrids. For two of them (PSHHIM and NBuHIA), estimates of gene copy number and ratio of human $(\alpha \mathrm{h})$ to mouse $(\alpha \mathrm{m}) \alpha$ mRNA were determined by using cells that had been grown and induced on two separate occasions. The band marked by the shaded arrow corresponds to a small amount of undigested mouse $\alpha$-globin probe. One hybrid (MELC/K562 II not shown) that contained less than one copy of human chromosome 16 per cell was examined in further detail. Probing with total human genomic DNA demonstrated that loss of the $\alpha$ complex was associated with a major rearrangement of chromosome 16 in a proportion of the cells. (Bottom) An example of carboxymethyl-cellulose chromatography of ${ }^{3} \mathrm{H}$-labeled globin chains from an induced interspecific hybrid (8E4) containing a normal $(\alpha \alpha)$ chromosome 16. $\alpha^{\mathrm{H}}$ and $\alpha^{\mathrm{M}}$ indicate the peaks of radioactivity corresponding to human and mouse $\alpha$-globin chains.

eight pools transformed with constructs containing this BgIII fragment. We also noted that construct 11 appeared to be integrated at higher copy numbers than any of the other fragments used, and the experiments were re- peated to obtain stable transformants with comparably low copy numbers.

The major positive regulatory sequences are contained within a 24-kb segment of DNA

Provisional analysis of the segment between coordinates 0 and -52 thus identified and localized a region containing positive regulatory sequences. However, two small regions had not been analyzed; and because the initial test fragments were nonoverlapping, other potentially important regions may have been bisected. Therefore, the expression of three cosmid constructs, each containing the $\alpha$ l-globin gene linked to large overlapping upstream segments and the $n e o^{\mathrm{R}}$ dominant selectable marker, was tested (Fig. 3). The cosmids were linearized with ClaI, transfected into MELCs, and selected for resistance to G418.

High levels of $\alpha$-globin mRNA transcripts $(22$ of 22 pools studied; Table 3 ) were only observed in cosmid construct 15 (Fig. 3), which contained DNA spanning the region that includes fragment 10 (Fig. 3). As before, most stable transformants containing this construct showed increased expression upon induction; those that had unusually high levels of human $\alpha$ mRNA prior to induction were less inducible. We also noted that the number of G418-resistant colonies obtained per microgram of DNA used in the transfection assay was considerably higher in experiments with this cosmid construct than the others and consequently suspected that sequences within this region were also exerting a positive effect on the heterologous promoter of the linked $n e o^{\mathrm{R}}$ gene. As noted previously for construct 11 , stable transformants containing this cosmid construct $(15)$ had a relatively high copy number, and experiments were repeated to obtain transformants with comparably low copy number.

To determine the relationship between copy number and $\alpha$-globin mRNA expression, MELCs were serially transfected with increasing amounts of construct 15 (2, 8 , and $15 \mu \mathrm{g} / 2 \times 10^{7} \mathrm{MELCs}$ ) and selected for resistance to G418; the number of colonies obtained in each experiment was directly related to the amount of DNA transfected (Fig. 5). Fifteen pools of stable transformants containing averages of $0.5-200$ copies of the construct per cell were analyzed (Fig. 5). In general, those pools containing the highest copy numbers of the human $\alpha$ gene expressed the greatest amount of human $\alpha$ mRNA (up to $300 \%$ of the endogenous mouse $\alpha$ mRNA). However, stable transformants containing low copy numbers (1-16 copies/cell) still expressed human $\alpha$-globin mRNA at high levels $(40-80 \%$ of the endogenous mouse $\alpha$ mRNA). This pattern was also observed in stable transformants containing construct 11. Thus, there is not a simple linear relationship between the gene copy number and the level of expression; at high copy numbers, the level of expression per gene copy appears to decrease.

Globin synthesis was analyzed in two pools of stable transformants (Fig. 5). In one containing a low copy number, the level of $\alpha$-globin synthesis was at the lower 
Figure 3. (Top) The $\alpha$-globin gene cluster as in Fig. 1. (Bottom) The extent of the deletion in the nonfunctional $(\alpha \alpha)^{\mathrm{RA}}$ chromosome (Nicholls et al. 1987) is indicated by a black bar. The fragments derived from plasmids (open boxes) and cosmids (stippled boxes) contained within various constructs (numbered) used to establish stable transformants in MELCs and transgenic mice. Fragments that had been analyzed previously in transgenic mice (Palmiter and Brinster 1986; Hanscombe et al. 1989; Ryan et al. 1989a) are indicated by crosshatched boxes. A detailed description of how each construct was made is given in Materials and methods. The $\alpha$-globin gene was inserted at the XhoI site at coordinate -5 in cRN24 $\alpha \mathrm{c}$ (construct 14 ).

end of the range seen when interspecific hybrids containing chromosome 16 were analyzed. In the other pool, containing multiple copies of construct 15 , human $\alpha$-globin synthesis represented $>300 \%$ of that produced by the endogenous genes.

It is not yet clear whether the region contained within the cosmid $(-28$ to -65$)$ and the segment contained within the BgIII fragment $(-37$ to -47$)$ produce significantly different levels of $\alpha$-gene expression. Nevertheless, these data, combined with observations on the naturally occurring deletion in the $(\alpha \alpha)^{\mathrm{RA}}$ chromosome $(+10$ to -52$)$ would suggest that major sequences responsible for high levels of $\alpha$-globin expression lie between coordinates -28 and -52 , and, at least in part, between -37 and -47 .
The remote positive regulatory region is associated with erythroid-specific DNase I hypersensitive sites

The stable transformant assay thus identified a single fragment (construct 15 ) that contains positive regulatory sequences that appear to behave in a similar manner to elements within the previously described $\beta$-globin DCR. The potential importance of the region containing the $\beta$-globin DCR was originally suspected because it contained four prominent, erythroid-specific DNase I hypersensitive sites (Tuan et al. 1985; Forrester et al. 1986, 1987). Furthermore, it has been shown that such tissuespecific DNase I hypersensitive sites generally map closely to the binding sites for trans-acting factors (for review, see Gross and Garrard 1988); the effect of the
Figure 4. (Top) The $\alpha$-globin complex, as described in Fig. 1. The extent of the nonfunctional $(\alpha \alpha)^{\text {RA }}$ deletion is indicated by a black bar. The fragments containing $(1-4)$ or linked to $(5-12)$ the $\alpha$-globin gene in each of the constructs (numbered) are indicated by open boxes. (Center) Examples of the relative levels of human $(\alpha \mathrm{h})$ and mouse $(\alpha \mathrm{m}) \alpha$ mRNA expression detected in $0.2-1 \mu \mathrm{g}$ of total RNA. (Bottom) Estimates of the $\alpha$-globin gene copy number for each of the constructs used in this series of experiments. (Left) Standards (0.5-4.0 gene copies per cell) and a control containing only mouse DNA $(\mathrm{m})$. Further details for each experiment are given in Table 2. Clearly, constructs 10 and 11 (i.e., the same BglII fragment linked to the $\alpha$ gene in opposite orientations are expressed at higher levels per gene copy than all other fragments. The single other example (construct 5) of a relatively high level of human $\alpha$ mRNA expression, albeit only $1 \%$ of the endogenous mouse gene, in these other constructs is shown for comparison. It should be noted that this level of expression was observed in only one of eight pools of stable transformants containing construct 5 . Because this was an isolated example, it seems most likely that this was related to its site of integration rather than an inherent property of this fragment. We also noted readily detectable levels of $\alpha$ mRNA in one other clone. This contained a particularly high copy number of fragment 7 for which the expression per gene copy was considerably less $(\sim 1-2 \%)$ than estimated for the endogenous gene.
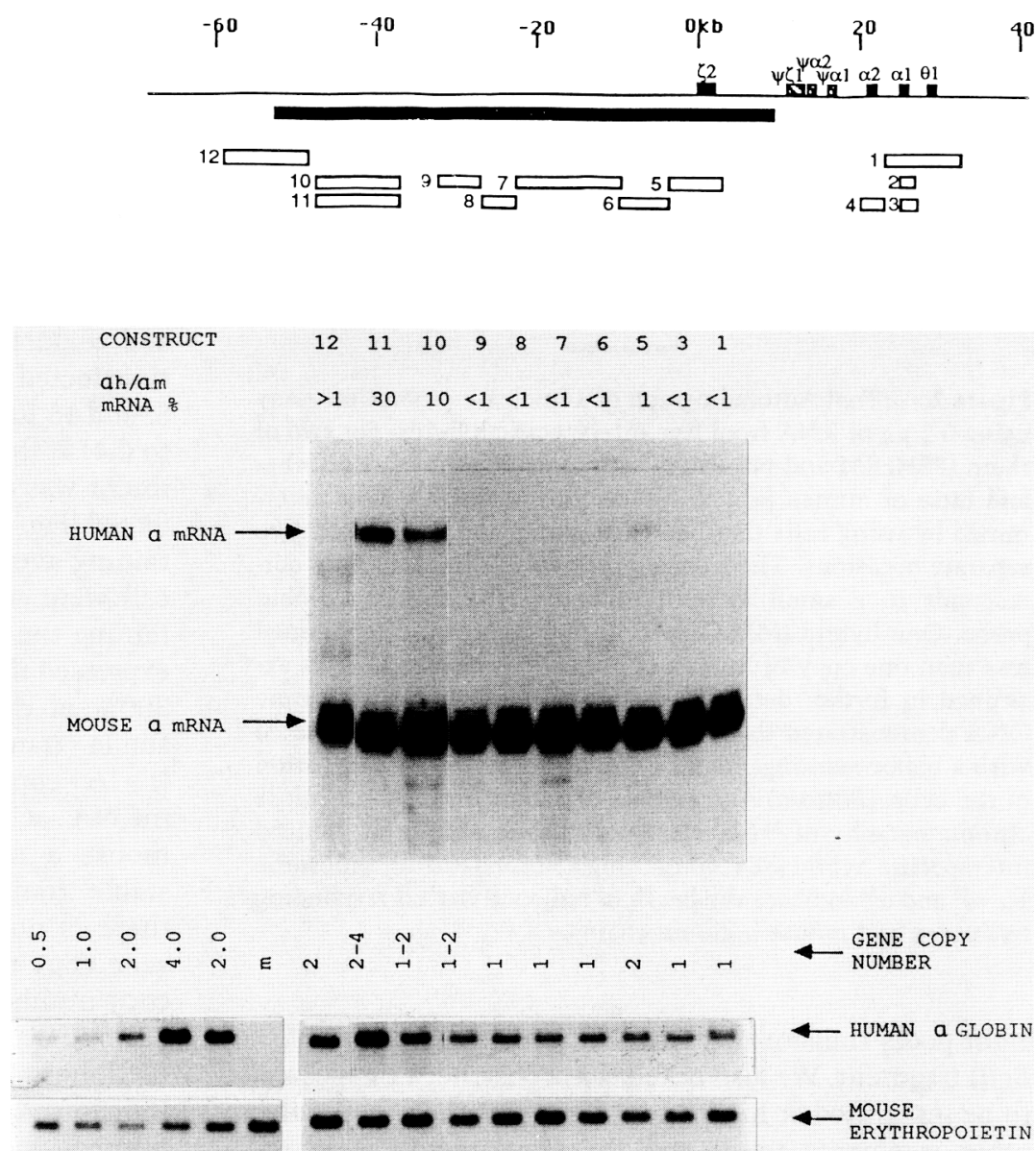
Table 2. a-Globin expression in stable transformants containing plasmid constructs 1-12

\begin{tabular}{|c|c|c|c|c|c|}
\hline $\begin{array}{l}\text { Fragment } \\
\text { studied }\end{array}$ & $\begin{array}{l}\text { Average } \\
\text { pool size } \\
\text { (range) }\end{array}$ & $\begin{array}{l}\text { Number of } \\
\text { positives } \\
\text { studied }\end{array}$ & $\begin{array}{l}\text { Average gene } \\
\text { copies per cell } \\
\text { (range) }\end{array}$ & $\begin{array}{l}\text { Percent average } \\
\text { expression } \alpha \mathrm{h} / \alpha \mathrm{m} \\
\text { (range) }\end{array}$ & $\begin{array}{l}\text { Percent average } \\
\text { expression } \alpha \mathrm{h} / \alpha \mathrm{m} \\
\text { mRNA/gene (range) }\end{array}$ \\
\hline 1 & $4(1-16)$ & 8 & $1(0.5-1)$ & $<1$ & $<1$ \\
\hline 2 & $150(60-190)$ & 3 & ND & $\mathrm{ND}$ & ND \\
\hline 3 & $5(1-11)$ & 6 & $1(0.5-1)$ & $<1$ & $<1$ \\
\hline 4 & $70(10-160)$ & 11 & ND & ND & ND \\
\hline 5 & $8(1-23)$ & 8 & 1 & 1 & $<1$ \\
\hline 6 & $14(1-60)$ & 11 & $2(0.5-4)$ & 1 & $<1$ \\
\hline 7 & $5(1-13)$ & 6 & 1 & $<1$ & $<1$ \\
\hline 8 & $12(1-34)$ & 15 & $1(0.5-1)$ & $<1$ & $<1$ \\
\hline 9 & $2(1-7)$ & 7 & $1(0.5-1)$ & $<1$ & $<1$ \\
\hline 10 & $9(1-32)$ & 9 & $1(1-2)$ & $14(2-27)$ & $50(8-108)^{a}$ \\
\hline 11 & $2(1-4)$ & 13 & $25(1-100)$ & $72(3-192)$ & $23(2-76)^{\mathbf{a}}$ \\
\hline 12 & $1(1-2)$ & 4 & $2(0.5-6)$ & $<1$ & $<1$ \\
\hline$\beta D C R-\alpha$ & $8(1-27)$ & 11 & $1(0.5-2)$ & $9(1-29)$ & $38(4-100)^{a}$ \\
\hline
\end{tabular}

$\alpha h$ indicates human $\alpha ; \alpha \mathrm{m}$ indicates mouse $\alpha$.

abecause expression of mRNA per gene copy appears to be less in transformants containing a high copy number (see text), these values are dependent on the proportion of samples containing high or low copy numbers in each series (see Fig. 3).

DCR could be mediated through such factors. We therefore analyzed the region of interest between coordinates -28 and -60 for the presence of hypersensitive sites. In particular, we wanted to determine whether erythroidspecific sites existed within the segment contained in the active BglII fragment (constructs 10 and 11).

As a source of erythroid cells we examined erythroblasts prepared from the liver of a 15-week-old fetus, an interspecific human $16 \times$ MELC hybrid $13 \mathrm{~A} 6$; see Materials and methods) and a cell line with some erythroid characteristics (K562). We also examined seven nonerythroid cell lines, including fibroblasts (GM3322), Epstein-Barr virus (EBV) B lymphocytes from a normal individual, a teratocarcinoma cell line (Tera-2), an adrenal carcinoma cell line (SW-13), a melanoma cell line (RVH 421 , and the HeLa cell line. In addition, DNase I hypersensitive sites were mapped in a stable transformant MELC line containing multiple copies of construct 15 spanning the region between coordinates -28 and -65 (referred to as cell line 28-3).

Nuclei from fetal erythroblasts and K562 were analyzed with a $\beta$-globin probe to ensure that they demonstrated the previously described hypersensitive sites associated with the $\beta$-globin DCR (see Fig. 6B, no. 1). Using probes from the $\alpha$-globin region (Fig. 6A), we iden- tified two prominent erythroid-specific hypersensitive sites at -33 (Fig. 6B, 3 and 5) and -40 (Fig. 6B, 6 and 7). These sites were present in nuclei obtained from fetal erythroblasts, K562, and the stable transformant 28-3 but absent in nuclei from lymphocytes (Fig. 6B, 4), Tera-2, SW-13, RVH 421, and HeLa cells. A less prominent hypersensitive site was seen in nuclei from fetal erythroblasts and $\mathrm{K} 562$ at coordinate -38 (shown as a small stippled arrow in Fig. 6A, with data shown in Fig. 6B, 3 and 91. It was of particular interest that one of the two prominent erythroid-specific sites $(-33)$, although present in construct 15 , maps to a small region not tested in our initial search for positive regulatory sequences and not included within constructs 10 and 11 .

In addition to these sites, we identified three less restricted sites. One, located at coordinate -36 (Fig. 6B, 3,4 , and 9| was present in nuclei from fetal erythroblasts, K562, 28-3, lymphocytes, and HeLa cells. Another, at coordinate -46 (Fig. 6B, 8), was present in nuclei from K562, 28-3, lymphocytes, SW-13, and Tera-2 cells. The other, at coordinate -56 (Fig. $6 \mathrm{~B}, 2$ ), was seen in nuclei from fetal erythroblasts, K562, and lymphocytes. The significance of these less restricted sites remains to be determined.

All of these sites are contained within the cosmid con-

Table 3. a-Globin expression in stable transformants containing cosmid constructs 13-15

\begin{tabular}{|c|c|c|c|c|c|}
\hline $\begin{array}{l}\text { Fragment } \\
\text { studied }\end{array}$ & $\begin{array}{l}\text { Average } \\
\text { pool size } \\
\text { (range) }\end{array}$ & $\begin{array}{l}\text { Number of DNA } \\
\text { positives studied }\end{array}$ & $\begin{array}{l}\text { Average gene } \\
\text { copies per cell } \\
\text { (range) }\end{array}$ & $\begin{array}{l}\text { Percent average } \\
\text { expression } \alpha \mathrm{h} / \alpha \mathrm{m} \\
\text { mRNA (range) }\end{array}$ & $\begin{array}{l}\text { Average expression } \\
\alpha \mathrm{h} / \alpha \mathrm{m} \text { mRNA/gene }\end{array}$ \\
\hline 13 & $2(1-3)$ & 6 & $1(1-2)$ & $<1$ & $<1$ \\
\hline 14 & $2(1-3)$ & 5 & $7(1-32)$ & $<1$ & $<1$ \\
\hline 15 & $20(3-57)$ & 22 & $87(1-200)$ & $104(4-302)$ & $17(0.5-160)^{\mathrm{a}}$ \\
\hline
\end{tabular}

$\alpha \mathrm{h}$ indicates human $\alpha ; \alpha \mathrm{m}$ indicates mouse $\alpha$.

aBecause expression of mRNA per gene copy appears to be less in transformants containing a high copy number (see text), this value is dependent on the proportion of samples containing high or low copy numbers (see Fig. 3). 

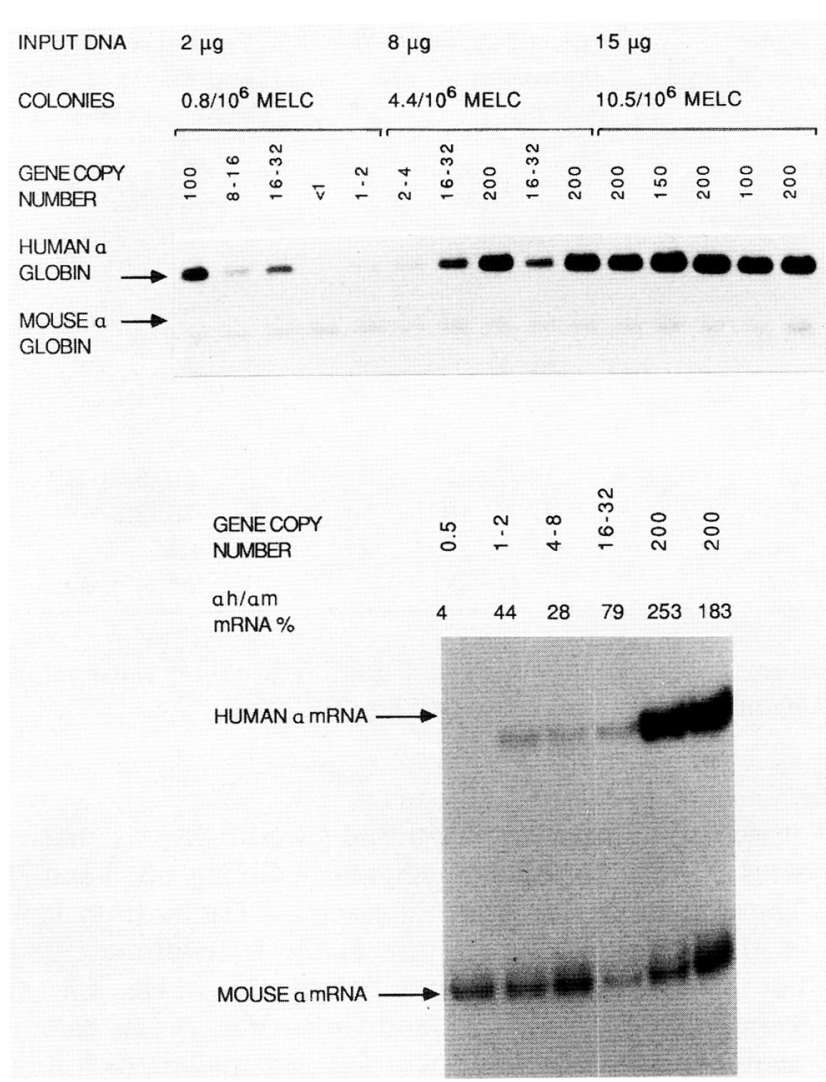
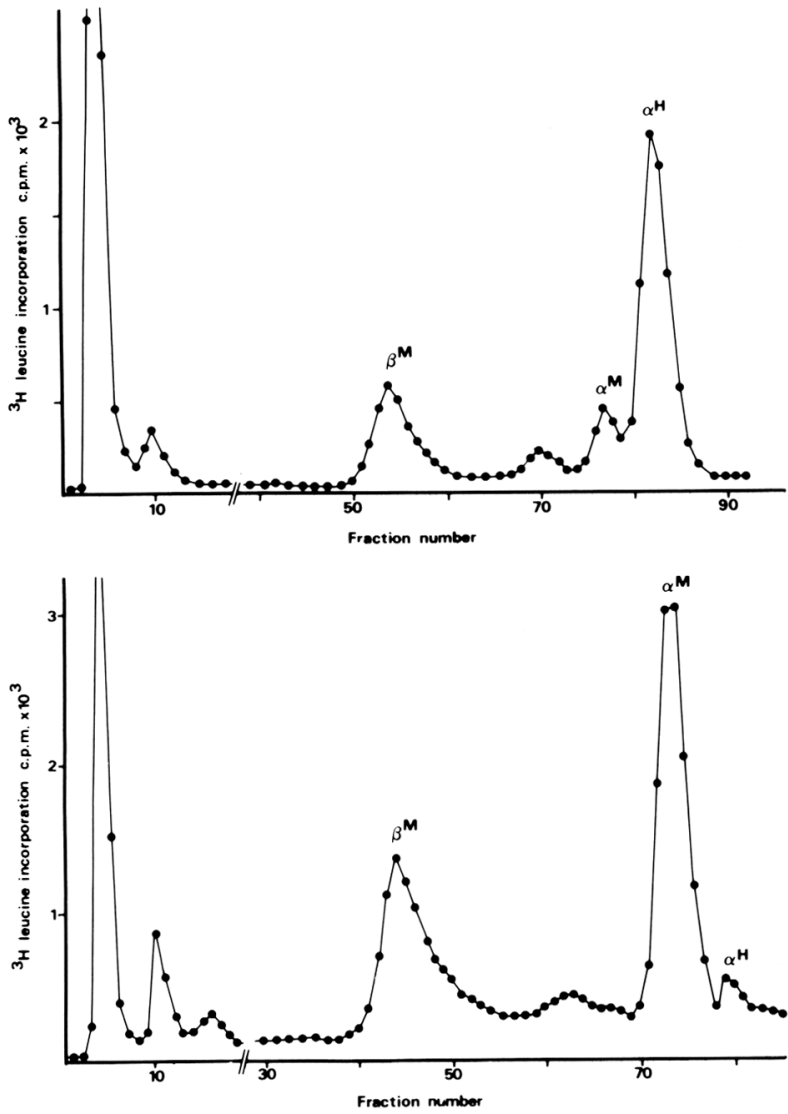

Figure 5. (Top left) Estimates of gene copy number in pools of stably transformed MELCs established by using 2-15 $\mu \mathrm{g}$ of DNA corresponding to construct 15. (Bottom left) Nuclease protection assay of $0.2 \mu \mathrm{g}$ of total RNA from pools of stable transformants containing 0.5-200 copies of construct 15. (Right) Carboxymethyl-cellulose chromatography of pools of stable transformants containing low (top) and high (bottom) copy numbers of construct 15. $\beta^{\mathrm{M}}, \alpha^{\mathrm{M}}$, and $\alpha^{\mathrm{H}}$ indicate the peaks of radioactivity corresponding to the mouse $\alpha$ and $\beta$ and human $\alpha$-globin chains, respectively.

struct, and one of the two erythroid-specific sites $(-40)$ also lies within the active BglII fragment identified by the MELC assay (summarized in Fig. 6). Other erythroid-specific hypersensitive sites and several constitutive hypersensitive sites were also noted outside of this region (data not shown) and around the structural $\alpha$ - and $\zeta$-globin genes, as identified previously by Yagi et al. (1986).

Constructs containing the $\alpha$-globin gene linked to the positive regulatory sequences are expressed at high levels and in a tissue-specific manner in transgenic mice

In previous experiments when fragments containing the $\alpha$-globin genes alone (e.g., fragments $16-18$, Fig. 3 ), or even containing the entire $\zeta / \alpha$-globin segment (fragment 19, Fig. 3), were introduced into transgenic mice, no human $\alpha$-globin expression was detectable (Palmiter and Brinster 1986; Hanscombe et al. 1989; Ryan et al. 1989a). We analyzed the expression of human $\alpha$-globin mRNA in transgenic mice containing the cosmid recombinants 14 or 15 , which together span the region be- tween 0 and -52 . Because it had been shown previously that mice containing the $\beta$-globin DCR linked to an $\alpha$ globin gene were severely anemic and might not survive until term (Hanscombe et al. 1989), we analyzed the transgenic mice as 13- to 18-day embryos. High levels of expression, representing $12-70 \%$ of the endogenous mouse $\alpha$-gene expression, were seen in those transgenic mice containing fragment 15 in which the $\alpha$ genes are linked to the positive regulatory sequences between coordinates -28 to -65 . In one of these transgenic mouse embryos, human $\alpha$-globin chains representing $5-10 \%$ of the mouse globin chains could be demonstrated (Fig. 7). However, despite the relatively high levels of $\alpha$-globin expression, none of the transgenic mouse embryos was overtly anemic, and the morphology of the erythroid precursors in the livers of the transgenic embryos was indistinguishable from that of their nontransgenic litter mates. It is possible that the only transgenic mouse embryos to survive to this gestational age are mosaics with relatively low transgene copy numbers in the hemopoietic tissues. However, against this, we observed no increased frequency of transgenic integration 11 of 18 in experiments using fragment 15 ) in embryos that were 

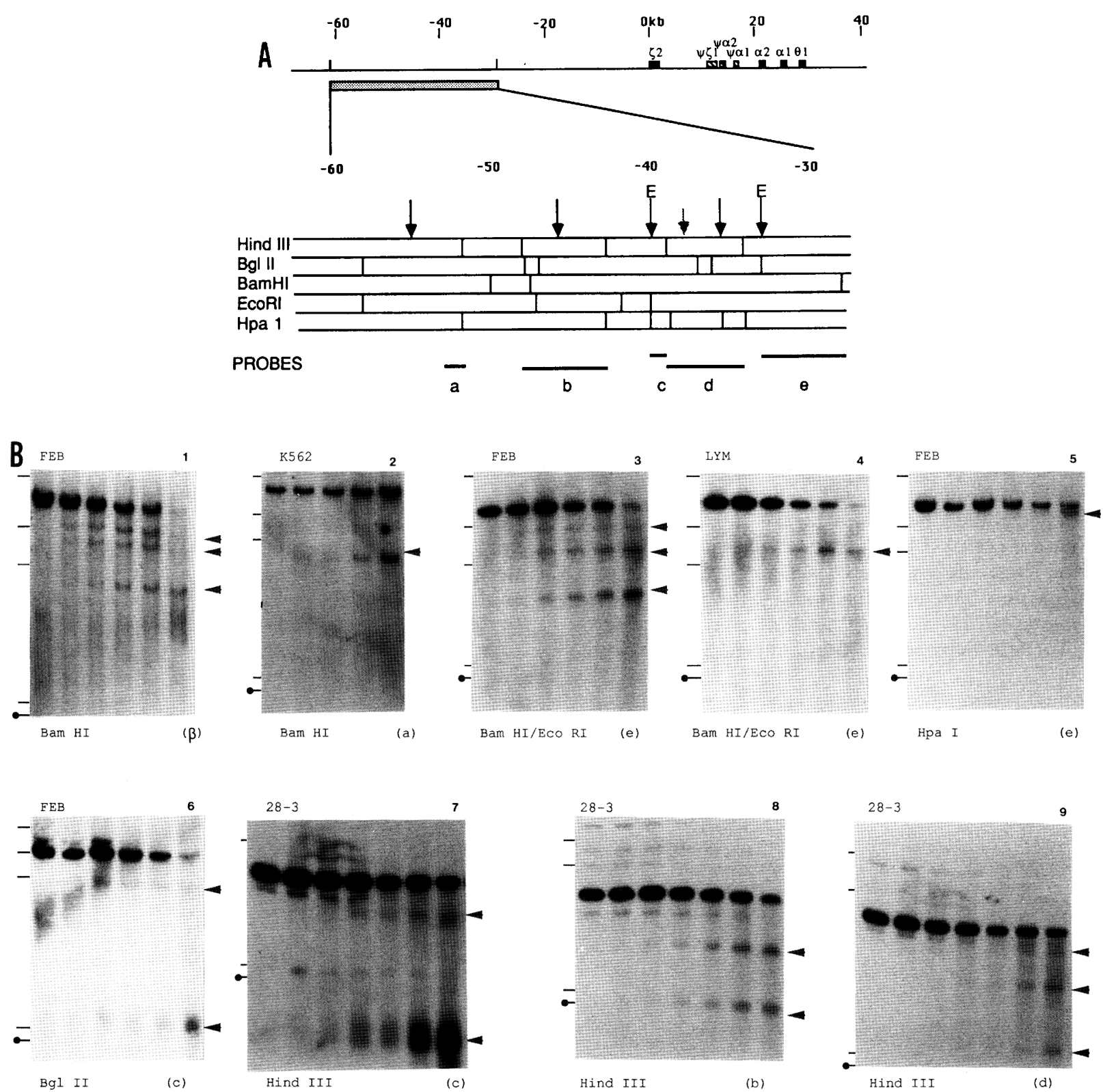

Figure 6. (A) Analysis of DNase I hypersensitive sites within the genomic region -30 to -60 is shown at top. (Bottom) This region is shown in detail with the positions of restriction sites (BamHI, BgIII, EcoRI, HindIII, and HpaI), hypersensitive sites (downward arrow), erythroid-specific sites (E), and probes a-e, as described in Materials and methods. (B) Examples of autoradiographs used to identify the hypersensitive sites as described in Materials and methods. Each autoradiograph referred to in the text is numbered at the top right hand corner. Size markers from $\lambda$ HindIII-cut DNA are shown at left [from top to bottom, 23, 9.6, 6.5, 4.3, 2.3, 2.0 (marked $\bullet-1)$. The positions of the hypersensitive sites are marked by arrowheads. (FEB) Fetal erythroblasts; (K562) erythroid cell line described in the text; (LYM) B lymphocytes; (28-3) stably transformed MELC line containing construct 15; (lane M) a nontransgenic mouse. Probes used for each experiment are indicated at the bottom righthand corner of each autoradiograph.

dead or in the process of being resorbed at the time of study.

To examine tissue specificity, each embryo containing construct 15 was dissected, and mRNA was isolated from liver, blood, and brain. For each transgenic mouse embryo, high levels of human $\alpha$ mRNA were only detected in the liver erythroblasts and peripheral blood (Fig. 7). Very small amounts of mouse and human $\alpha$ - globin mRNA detected in the brain could be accounted for by contamination of this tissue with whole blood.

\section{Discussion}

We have identified a region upstream of the $\alpha$-globin complex that confers high-level expression on linked $\alpha$ globin genes in erythroid cells. The evidence for this comes from several independent observations. First, 
cloned DNA fragments of up to $30 \mathrm{~kb}$ containing the $\alpha$-globin genes are poorly expressed when transfected into MELCs and are subject to position effects, depending on the site of integration. However, when a fragment containing the region from 28 to $65 \mathrm{~kb}$ upstream of the $\zeta$ gene is placed adjacent to an $\alpha$-globin gene, high levels of $\alpha$-gene expression (approximately equal to that observed when intact chromosomes are transferred to MELC) are observed in all transfectants. Preliminary observations suggest that this fragment may also act on a heterologous promoter $\left(n e o^{\mathrm{R}}\right)$. The area between this upstream region and the $\alpha$ complex itself does not enhance $\alpha$-gene expression in this way, either as relatively small $(5-14 \mathrm{~kb})$ fragments or as a large $\sim 35$-kb cosmid fragment. Second, neither the $\alpha$-globin genes alone nor a $30-\mathrm{kb}$ fragment containing most of the $\alpha$ complex has resulted in $\alpha$ mRNA transcription when integrated into $>60$ transgenic mice (Palmiter and Brinster 1986; Hanscombe et al. 1989; Ryan et al. 1989a), yet the upstream fragment attached to an $\alpha$ gene resulted in readily detectable transcripts in the erythroid tissues (but not the brain) of four of four transgenic fetuses examined. Third, the $\beta$-globin DCR is marked by four erythroid-specific hypersensitive sites (Tuan et al. 1985; Forrester et al. 1986, 1987). Similarly, prominent erythroid-specific hypersensitive sites were found within those fragments that confer high-level expression on adjacent $\alpha$-globin genes. Finally, the localization of these positive regulatory sequences is consistent with observations on two different naturally occurring deletions that remove this region but leave the structural $\alpha$-globin genes intact and give rise to the phenotype of $\alpha$ thalassemia. In one of these (Hatton et al. 1990), the region between +10 and -52 has been deleted (Fig. 1); in the other (A.O.M. Wilkie et al., in prep.), the region between -30 and the telomere of chromosome 16 has been deleted. The overlap between these two deletions $\mid-30$ to -52 ) corresponds to the segment of DNA containing the positive regulatory region described here. We therefore conclude that this region contains a major determinant of $\alpha$-gene expression.

It has been reported that the level of transcription of the $\beta$-globin gene under control of the $\beta$ DCR is copy number dependent in transfected cells and transgenic animals, although the evidence is based on relatively small numbers (Grosveld et al. 1987; Blom van Assendelft et al. 1989; Hanscombe et al. 1989) and has not been consistently observed between different laboratories (Curtin et al. 1989; Ryan et al. 1989b). Constructs containing the positive regulatory region from upstream of the $\alpha$ complex linked to an $\alpha$ gene show some relationship between copy number and transcript levels but

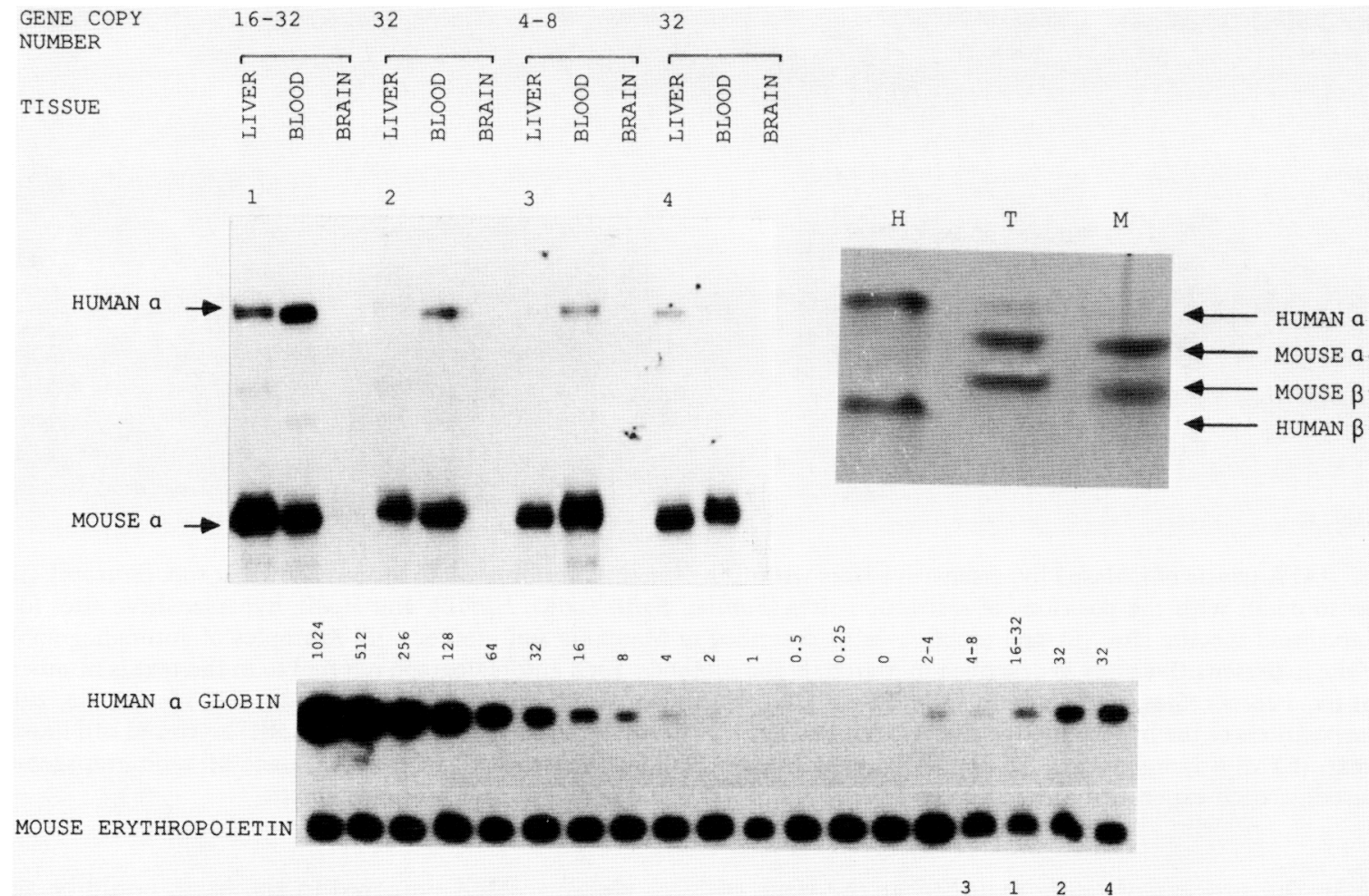

Figure 7. (Top left) Examples of nuclease protection assays using 50-300 ng of total RNA from four transgenic mice [gestational ages: (1) 17 days; (2) 14 days; (3) 14 days; (4) 13 days] containing construct 15. (Bottom) Estimates of gene copy number in each of the mice $(1-4)$ compared with a set of predetermined standards $(0-1024$ copies per cell; see Materials and methods). The integrity of each construct was tested by analysis of a BamHI digest by using the entire cosmid cNFG-CL9 as a probe. (Top right) Analysis of human and mouse globin chains by denaturing cellulose acetate electrophoresis. (Lane $H$ ) human; (lane $T$ ) a transgenic mouse containing construct 15; (lane $M$ ) a nontransgenic mouse. 
certainly not a linear one; as copy number increases, the number of transcripts per gene copy appears to fall off quite rapidly. It is not clear whether this may signify a difference between the $\beta$-globin DCR elements and the upstream regulatory region of the $\alpha$-globin cluster or whether copy number dependence only obtains over a narrow range. It would not be surprising if some transcriptional factors became limiting when high copy numbers were present. In the experiments described here in both stable transformants and transgenic mice, the copy number range was higher than that reported for the $\beta$ DCR; the difficulty in obtaining cells with low copy number, which was only observed with constructs containing the positive regulatory region from upstream of the $\alpha$ complex, may suggest that this sequence, itself, is responsible for this characteristic.

Clearly, to understand how the $\alpha$ - and $\beta$-globin gene complexes are coordinately regulated, it will be important to estimate the relative effects of the $\alpha$-globin positive regulatory region and the $\beta$-globin DCR. In some transgenic mice with the $\beta$-globin DCR placed upstream of the $\alpha$-globin gene (Hanscombe et al. 1989), the expression of $\alpha$ mRNA appeared greater than in comparable experiments described here. Transgenic mouse embryos containing the full $\beta$-globin DCR linked to the $\alpha$-globin gene suffered from severe anemia, thought to be due to globin chain imbalance (Hanscombe et al. 1989). Embryos containing $\beta$-globin DCR hypersensitive sites I and II linked to the $\alpha$-globin gene did not appear to develop anemia (Ryan et al. 1989b). On this point, it was of interest that unlike transgenic mice containing fragments $16-19$, in which no human $\alpha$ mRNA could be detected (Palmiter and Brinster 1986; Hanscombe et al. 1989; Ryan et al. 1989a), low levels of human $\alpha$ mRNA were detected in a transgenic mouse containing fragment 14 (at high copy number), which includes at least two erythroid-specific hypersensitive sites between coordinates 0 and -14 (D.R. Higgs, unpubl.). Other cisacting sequences, lying outside of the $\alpha$-globin complex, may act synergistically with this region to regulate $\alpha$ gene transcription, although we have ruled out any major transcription enhancing activity from these areas on their own. Therefore, it is not yet clear whether the sequences between -28 and -65 contain all of the elements that constitute the full $\alpha$-globin DCR.

The apparent similarity in the position, structure, and function of the region upstream of the $\alpha$ genes and elements within the $\beta$-globin DCR is in marked contrast to differences in other structural and functional characteristics of the two gene complexes (see introductory section). These features previously have been implicated as playing an important role in the control of eukaryotic gene expression, yet for the coordinated regulation of the globin clusters it may be that any such roles are subservient to the overriding effect of these major positive regulatory regions. Clearly, it will be necessary to determine the sequence of the positive regulatory region upstream of the $\alpha$ cluster and analyze its interactions with ubiquitous and tissue-restricted trans-acting factors to determine whether the gross similarities to elements within the $\beta$ DCR are reflected at a more detailed level and to determine which features may be responsible for coordinately regulating transcription from these separate clusters.

\section{Materials and methods}

\section{Construction of recombinants and fragments}

Fragments 1-3 (Fig. 3) were obtained from previously described recombinants. Fragment 1 is an $8.4-\mathrm{kb}$ BglII fragment containing the $\alpha 1$ gene from $\mathrm{c} \alpha^{\prime}{ }^{\prime} \mathrm{Bg}$ (Nicholls et al. 1987), fragment 2 is a $1.5-\mathrm{kb}$ PstI fragment containing the $\alpha 1$ gene from $\mathrm{pRB} \alpha 1$ (Lauer et al. 1980), and fragment 3 is a $2.4-\mathrm{kb}$ MstII fragment containing the $\alpha$ l gene from $\mathrm{pRB} \alpha 1$.

Recombinant fragments 4-12 were all constructed in the vector pNXKN (a gift from R.W. Jones), which contains a polylinker including two NotI sites between the EcoRI and HindIII sites of pSP64 (Melton et al. 1984). A 2.0-kb PvuII fragment containing the $\alpha 2$-globin gene from pSst $\alpha 2$ (a recombinant containing the genomic SstI fragment, including the $\alpha 2$ gene in pBR322) was inserted into an XhoI site in the polylinker of pNXKN to give pNXKN $\alpha 23$. Subsequently, BamHI, BglII, or $B a m H I-B g l$ II fragments spanning the region 0 to -62 were subcloned into a unique $B a m H I$ site in the polylinker next to the $\alpha 2$ gene in pNXKN 223 . Each of these upstream fragments (see Fig. 3) was cloned into pNXKNa23 in both orientations with respect to the $\alpha 2$-globin gene. Fragments containing either the $\alpha 2$ gene alone (fragment 4) or the $\alpha 2$ gene linked to one of the upstream fragments (fragments 6-12) were released from the vector following digestion with NotI. Each recombinant fragment was gel-purified (Maniatis et al. 1982) prior to electroporation into MELCs.

A recombinant containing a segment from the $\beta$-globin DCR was constructed by inserting the $6-\mathrm{kb} B a m H I-B g I I I$ fragment spanning coordinates +4 to +10 of the $\beta$-globin cluster (as set out in Grosveld et al. 1987) into the BamHI site of pNXKNa23. As before, the entire fragment was subsequently purified following NotI digestion of this recombinant.

For the cotransfection experiments, a 7.8-kb HindIII fragment containing the hamster APRT gene was isolated from pHaprt-1 (Lowy et al. 1980) and prepared by gel purification, as described above.

Recombinants containing the large overlapping fragments $\{13-15$, Fig. 3\} were prepared as follows. Fragment 13 includes the entire $\alpha$-globin complex in a cosmid vector derived from pJB8 and is referred to as pCL9 (Lau and Kan 1983). Fragment 14 was constructed by inserting a BgIII-EcoRI fragment containing the $\alpha 1$ gene into an XhoI site at the $3^{\prime}$ end of the previously described cosmid cRN24 (Nicholls et al. 1987) by using XhoI linkers (Maniatis et al. 1982; see legend to Fig. 3); this is referred to as cRN24 $\alpha$ c. Fragment 15 was constructed from pCL9 and cosmid cNFG2, described previously (Nicholls et al. 1987). pCL9 was cut with SstI; subsequently, blunt ends were created at these sites by using mung bean nuclease (Maniatis et al. 1982). This was then recut with ClaI, and the 14-kb blunt/ ClaI fragment containing the $\alpha \mathrm{l}$ gene and vector sequences was isolated by gel purification. The insert from cNFG2 was cut with $H p a I$, and blunt ends were generated with mung bean nuclease; this was recut with ClaI, and the $40-\mathrm{kb}$ blunt/ClaI insert fragment was purified. The $\mathrm{CNFG} 2$ insert and $\mathrm{pCL} 9$ vector $/ \alpha 1$ fragment were then ligated together, reforming the $\mathrm{Cla}$ I site to produce cNFG-CL9. Each of these cosmid recombinants was linearized with $\mathrm{ClaI}$ and purified prior to electroporation or injection into transgenic mice. 
Isolation and characterization of interspecific somatic cell hybrids

Somatic cell hybrid lines were made by the methods of Deisseroth and Hendrick (1979), as modified by Zeitlin and Weatherall (1983). Either EBV-transformed lymphocytes (cell lines JWH2C-4, -6, and $-8, \mathrm{NBuH1A1}$, and PSHHIM 1), peripheral blood mononuclear cells (cell lines 3A6, 7A1, 2A2), or fetal liver erythroblasts $(8 \mathrm{~B} 6,8 \mathrm{E} 4)$ containing nonthalassemic chromosomes were fused with an APRT-negative MELC (line 585, a gift from A. Deisseroth). Hybrid cells containing human chromosome 16 were selected in medium containing methotrexate $(0.1 \mathrm{~mm})$, adenine $(0.1 \mathrm{mM})$, thymidine $(30 \mu \mathrm{M})$ and ouabain $\{0.5$ $\mu \mathrm{M})$. Ouabain was only included during the first 14 days of culture to prevent the background growth of EBV-transformed lymphocytes in preference to the mouse/human hybrid cells. To study $\alpha$-globin gene expression, hybrid cell lines were induced with DMSO $(1.4 \% \mathrm{vol} / \mathrm{vol})$ and hemin $(40 \mu \mathrm{M})$ or HMBA (5 mM) for 3 days prior to analysis of RNA and globin chain synthesis.

\section{Isolation and characterization of stable transformants in $M E L C$}

Stable transformants in MELC were obtained by cotransfection of APRT-negative MELCs with $1 \mu \mathrm{g}$ of hamster APRT gene (7.8kb HindIII fragment; Lowy et al. 1980) and a 10-fold molar excess of the $\alpha$-globin gene constructs. The cell line was a semiadherent derivative of line 585 , which was cloned and selected for a high level of inducibility prior to these experiments and maintained in RPMI and 15\% FCS. Transfection was carried out by electroporation, with laboratory-designed equipment (R.W. Jones and G.T. Warner), at $400 \mathrm{~V}$ and $1000 \mu \mathrm{F}$ in $\mathrm{Ca}^{2+} \mathrm{Mg}^{2+}$-free Hank's balanced salt solution. Transfected cells were maintained in nonselective medium for $24 \mathrm{hr}$, during which time the surviving cells $(\sim 50 \%)$ reattached to the culture dish. Selection for APRT + ve cells was carried out in RPMI medium containing methotrexate $\left(10^{-5} \mathrm{M}\right)$, adenine $\left(10^{-4} \mathrm{M}\right)$, hypoxanthine $\left(10^{-4} \mathrm{M}\right)$, and thymidine $\left(3 \times 10^{-5} \mathrm{M}\right)$. In the selective medium, dead cells detached from the bottom of the flask and were removed when the medium was changed. Transfected cells expressing the hamster APRT gene grew as individual clones and were counted after 5-7 days. Each flask was maintained in selective medium until a cell count of $\sim 2 \times 10^{7}$ was achieved, when a proportion of the cells were harvested for DNA analysis and the remainder were induced with 5 mM HMBA for 3 days for RNA analysis. For cosmid constructs containing the $n e o^{\mathrm{R}}$ gene, electroporation was carried out with 2-20 $\mu \mathrm{g}$ of DNA, omitting the hamster APRT fragment, and selection was carried out in $0.8 \mathrm{mg} / \mathrm{ml} \mathrm{G} 418$ (Sigma).

\section{DNA analysis and estimation of gene copy number}

Southern blot analysis was carried out as described previously (Old and Higgs 1983). To estimate gene copy number, a set of DNA samples was prepared by serial $(\times 2)$ dilutions of $\sim 1 \mu \mathrm{g}$ of a 1.5-kb PstI fragment, from the recombinant $\mathrm{pRB} \alpha 1$ (Lauer et al. 1980) in aliquots of a pooled sample of DNA obtained from fetal mice. This set of dilutions was standardized against DNA from a previously described hybrid cell line (H-101) known to contain one copy of chromosome 16 (and thus two copies of the $\alpha$ gene/ per cell. A second set of standards representing $0.5-4.0$ copies of the $\alpha$-globin gene per cell was produced by mixing mouse and human cells in measured proportions prior to DNA extraction. Approximately $5 \mu \mathrm{g}$ of DNA from each standard sample was compared with $5 \mu \mathrm{g}$ of DNA from either the interspecific hybrids or stably transformed MELCs. Each filter was hybridized with either a human $\alpha$-globin probe (a $1.0-\mathrm{kb}$ HindIII-PstI fragment from $\mathrm{pRB} \alpha 1)$ and a mouse $\alpha$-globin probe [0.5-kb Pst fragment from pUC $\mathrm{m} \alpha$ (Baron and Maniatis 1986)] or the human $\alpha$ probe and a mouse erythropoietin probe (a PstI fragment from the recombinant pMs Psti; a gift from Dr. E. Goldwasser). Autoradiographs, representing 12-hr to 5-day exposures were subsequently scanned by using a LKB Ultrascan laser scanner to determine the relative intensities of the human $\alpha$-globin and mouse signals.

\section{RNA analysis}

Total RNA was prepared from cell pellets $\left(2 \times 10^{7}\right.$ to $5 \times 10^{7}$ cells), mouse fetal liver, brain, or blood by the method of Chomczynski and Sacchi (1987). Human and mouse $\alpha$-globin mRNA was detected using the quantitative RNase mapping procedure (Zinn et al. 1983). Approximately $1 \mu \mathrm{g}$ of a plasmid [pSP6 132 (Baron and Maniatis 1986)], containing an insert corresponding to the $5^{\prime}$ end of both the human $\alpha 1$ - and $\alpha 2$-globin genes, was linearized with BamHI. Similarly, $1 \mu \mathrm{g}$ of plasmid (pSPJM $\alpha$ S, a gift from R.W. Jones) containing a PstI-Ball fragment corresponding to the $5^{\prime}$ end of the mouse $\alpha$ gene was linearized with HindIII. A ${ }^{32} \mathrm{P}$-labeled probe was transcribed from each template by using SP6 polymerase as specified in the SP6 system (Amersham International plc) and $\left[\alpha^{-32}\right.$ P $]$ GTP $(410 \mathrm{Ci} /$ mmole; Krieg and Melton 1984; Melton et al. 1984). Each probe $\left(\sim 1 \times 10^{6} \mathrm{cpm}\right)$ was added separately to $1-10 \mu \mathrm{g}$ of total cellular RNA (see figure legends), heated to $95^{\circ} \mathrm{C}$ for $10 \mathrm{~min}$, and hybridized in $80 \%$ formamide, $40 \mathrm{~mm}$ PIPES ( $\mathrm{pH} 6.4$ ), $400 \mathrm{~mm}$ $\mathrm{NaCl}$, and $1 \mathrm{~mm}$ EDTA, at $50^{\circ} \mathrm{C}$ overnight. In two experiments during the course of this study, fixed amounts of probe $\left(0.5 \times 10^{6} \mathrm{cpm}\right)$ were titrated against increasing amounts of RNA $(1-20 \mu \mathrm{g})$; and in one experiment, varying amounts of probe $\left(0.5 \times 10^{5}\right.$ to $\left.2 \times 10^{6} \mathrm{cpm}\right)$ were titrated against a fixed amount of RNA $(2 \mu \mathrm{g})$ to ensure that assays were carried out in probe excess. The resulting RNA-RNA hybrids were then treated with RNases A $(40 \mu \mathrm{g} / \mathrm{ml})$ and $\mathrm{T}^{1}(2 \mu \mathrm{g} / \mathrm{ml})$ at ambient room temperature for $30 \mathrm{~min}$. The protected fragments $[93$ nucleotides for mouse $\alpha$ (R.W. Jones, pers. comm.) and $133 \mathrm{nu}$ cleotides for both human $\alpha 1$ and $\alpha 2$ (Baron and Maniatis 1986) were analyzed on $8 \%$ acrylamide $/ 8 \mathrm{M}$ urea-denaturing gels. To estimate the relative amounts of human and mouse $\alpha$ mRNA, the bands corresponding to each protected fragment were located, excised from the gel, placed in $5 \mathrm{ml}$ of scintillant (Liquiscint, National Diagnostics), and counted for $10 \mathrm{~min}$. To allow comparison of levels of mRNA from one experiment to another, an aliquot of mRNA from the stable transformant $28-2$ was included on each gel and relevant samples were also reanalyzed on the same gel by using a single batch of each probe.

\section{Analysis of human and mouse globin chains}

Globin chain synthesis was carried out as described previously (Zeitlin and Weatherall 1983). To analyze human and mouse globin chains in the peripheral blood of transgenic mice, an equal volume of water was added to $5 \mu$ l of packed red cells. One volume of the lysate was added to an equal volume of 7.5 $\mathrm{M}$ urea in a buffer [0.15 $\mathrm{M}$ Tris- $\mathrm{HCl}(\mathrm{pH} 8.6), 6 \mathrm{mM}$ EDTA, and $50 \mathrm{~mm}$ boric acid] and $1-1.5$ volumes of mercaptoethanol. Five microliters of this was run on cellulose acetate strips $(300 \mathrm{~V}$ for $1-1.5 \mathrm{hr}$ ) that had been soaked previously for several hours in the buffer without mercaptoethanol. The proteins were subsequently stained with Ponceau S and destained in 5\% acetic acid to identify the human and mouse globin chains (Huisman and Jonxis 1977). 


\section{Identification of DNase I hypersensitive sites}

Nuclei were prepared from a variety of tissues and cell lines. Fetal erythroblasts were prepared by finely mincing a fetal liver sample (15 weeks gestation) into $\mathrm{Ca}^{2+} \mathrm{Mg}^{2+}$-free Hank's balanced salt solution and washing three times. After transfer of the cells to RPMI culture medium, aggregates of hepatocytes were allowed to settle out for $15 \mathrm{~min}$ on ice followed by centrifugation ( $\sim 500 \mathrm{rpm}$ for $2 \mathrm{~min})$. Cells in suspension comprised $\sim 80 \%$ erythroid cells. K562 cells (Rutherford et al. 1979), a MELC line containing human chromosome 16 (3A6), a stable transformant of construct 15 in MELC (28-3), an EBV-transformed B-lymphocyte line, teratocarcinoma cell line (Thompson et al. 1984), melanoma cell line (McCormick et al. 1983), fibroblasts (GM3322), the HeLa cell line, and adrenal carcinoma cell line (Leibovitz et al. 1973) were grown to mid-log phase. Approximately $10^{8}$ cells from each of these were washed (two to three times) at $4^{\circ} \mathrm{C}$ in phosphate-buffered saline. The cells were lysed by mixing for $30-60 \mathrm{sec}$ in $0.2-0.5 \%$ Nonidet $\mathrm{P}-40$ in RSB [10 mM NaCl, $10 \mathrm{~mm}$ Tris- $\mathrm{HCl}(\mathrm{pH} 7.5), 3 \mathrm{~mm}$ $\mathrm{MgCl}_{2}$ ] at $4^{\circ} \mathrm{C}$, and nuclei were recovered by low-speed centrifugation $(\sim 1000 \mathrm{~g})$ for $7 \mathrm{~min}$. Nuclei were washed (three times) in RSB prior to resuspension in $1 \mathrm{ml} \mathrm{RSB}$ and digested with $20-40$ units of DNase I $(20,000 \mathrm{U} / \mathrm{ml}$ Pharmacia FPLC pure $)$ at $37^{\circ} \mathrm{C}$ for 0-60 min. Following digestion, DNA from each time point was phenol-chloroform-extracted prior to digestion with a variety of enzymes, as described in the legend to Figure 6. Southern blots of these time course experiments were probed with fragments from the region -30 to -60 of the $\alpha$-globin locus. The probes are as follows: (a) a previously described 330bp fragment RA330 (Nicholls et al. 1987); (b) a 5-kb HindIII fragment from $\mathrm{pMCHd} 2$, spanning -43 to -48 ; (c) a fragment described previously, RAl.4 (Nicholls et al. 1987); (d) a 5.5-kb HindIII fragment from the plasmid pMCHd1, spanning -34 to -39.5 ; (e) a fragment described previously, L4 (Nicholls et al. 1987); ( $\beta$ ) a 0.46-kb EcoRI-BgIII fragment from approximately coordinate 20 of the $\beta$-globin cluster, as described in Grosveld et al. (1987) (a gift from Dr. D. Greaves).

\section{Preparation of transgenic mice}

Transgenic mice were produced by the method of Murphy and Hanson (1987). Following superovulation, eggs were removed from oviducts of sib-mated donor (CBA $\times$ C57B $)$ F1 mice. Construct DNA was purified on a Sephadex- 50 column, diluted in injection buffer, and filtered at $0.2 \mu \mathrm{m}$ to a final concentration of $1,2.5$, or $5 \mu \mathrm{g} / \mathrm{ml}$. The DNA fragments were injected into the pronuclei of fertilized eggs, which were then maintained in nutrient media as described by Murphy and Hanson (1987) for 4-20 hr. Injected eggs were transferred into the oviducts of pseudopregnant foster mothers of the same mouse strain, usually at a rate of 10-12 eggs per side.

\section{Acknowledgments}

We are grateful to Professor D.J. Weatherall for his generous help, support, and encouragement throughout. We also thank Drs. F. Grosveld and D. Greaves for useful discussions and support at the outset of this project. We thank Drs. P.C. Harris and $\mathrm{H}$. Zeitlin for providing some of the interspecific hybrids analyzed here, and Dr. V.J. Buckle for cytogenetic analysis of the cell line MELC/K562 II. We also thank Drs. M.A. Vickers, A.O.M. Wilkie, P. Vyas, R.W. Jones, and B. Morley for their encouragement and comments on the manuscript. We are also grateful to Professor L. Luzzatto for his help and for introducing us to J.L. Thanks also go to Liz Rose for her excellent secretarial help. The transgenic animal work was supported partly by the M.M.B. and A.F.R.C.

The publication costs of this article were defrayed in part by payment of page charges. This article must therefore be hereby marked "advertisement" in accordance with 18 USC section 1734 solely to indicate this fact.

\section{References}

Anagnou, N.P., T.Y. Yuan, E. Lim, J. Helder, S. Weider, D. Glaister, B. Marks, A. Wang, D. Colbert, and A. Deisseroth. 1985. Regulatory factors specific for adult and embryonic globin genes may govern their expression in erythroleukemia cells. Blood 65: 705-712.

Baron, M.H. and T. Maniatis. 1986. Rapid reprogramming of globin gene expression in transient heterokaryons. Cell 46: $591-602$.

Beggs, A.H. and B.R. Migeon. 1989. Chromatin loop structure of the human $\mathrm{X}$ chromosome: Relevance to $\mathrm{X}$ inactivation of CpG clusters. Mol. Cell. Biol. 9: 2322-2331.

Behringer, R.R., T.M. Ryan, M.P. Reilly, T. Asakura, R.D. Palmiter, R.L. Brinster, and T.M. Townes. 1989. Synthesis of functional human hemoglobin in transgenic mice. Science 245: $971-973$.

Bird, A.P., M.H. Taggart, R.D. Nicholls, and D.R. Higgs. 1987. Non-methylated CpG-rich islands at the human $\alpha$-globin locus: Implications for evolution of the $\alpha$-globin pseudogene. EMBO J. 6: 999-1004.

Blom van Assendelft, G., O. Hanscombe, F. Grosveld, and D.R. Greaves. 1989. The $\beta$-globin dominant control region activates homologous and heterologous promoters in a tissuespecific manner. Cell 56: 969-977.

Charnay, P., R. Treisman, P. Mellon, M. Chao, R. Axel, and T. Maniatis. 1984. Differences in human $\alpha$ - and $\beta$-globin gene expression in mouse erythroleukemia cells: The role of intragenic sequences. Cell 38: 251-263.

Chomczynski, P. and N. Sacchi. 1987. Single-step method of RNA isolation by acid guanidinium thiocyanate-phenolchloroform extraction. Anal. Biochem. 162: 156-159.

Collis, P., M. Antoniou, and F. Grosveld. 1990. Definition of the minimal requirements within the human $\beta$-globin gene and the dominant control region for high level expression. EMBO I. 9: 233-240.

Curtin, P.T., D. Liu, W. Liu, J.C. Chang, and Y.W. Kan. 1989. Human $\beta$-globin gene expression in transgenic mice is enhanced by a distant DNase I hypersensitive site. Proc. Natl. Acad. Sci. 86: 7082-7086.

Deisseroth, A. and D. Hendrick. 1979. Activation of phenotypic expression of human globin genes from nonerythroid cells by chromosome-dependent transfer to tetraploid mouse erythroleukemia cells. Proc. Natl. Acad. Sci. 76: 21852189.

Efstratiadis, A., J.W. Posakony, T. Maniatis, R.M. Lawn, C. O'Connell, R.A. Spritz, J.K. DeRiel, B.G. Forget, S.M. Weissman, J.L. Slightom, A.E. Blechl, O. Smithies, F.E. Baralle, C.C. Shoulders, and N.J. Proudfoot. 1980. The structure and evolution of the human $\beta$-globin gene family. Cell 21: 653-668.

Enver, T., A.J. Ebens, W.C. Forrester, and G. Stamatoyannopoulos. 1989. The human $\beta$-globin locus activation region alters the developmental fate of a human fetal globin gene in transgenic mice. Proc. Natl. Acad. Sci 86: 7033-7037.

Epner, E., W.C. Forrester, and M. Groudine. 1988. Asynchronous DNA replication within the human $\beta$-globin gene locus. Proc. Natl. Acad. Sci. 85: 8081-8085. 
Fei, Y.J., S. Fujita, and T.H.J. Huisman. 1988. Two different theta $(\theta)$ globin gene deletions observed among black newborn babies. Br. J. Haematol. 68: 249-253.

Fischel-Ghodsian, N., R.D. Nicholls, and D.R. Higgs. 1987a. Long range genome structure around the human $\alpha$-globin complex analyzed by PFGE. Nucleic Acids Res. 15: 61976207.

- 1987b. Unusual features of CpG-rich (HTF) islands in the human $\alpha$-globin complex: Association with nonfunctional pseudogenes and presence within the 3 ' portion of the $\zeta$ gene. Nucleic Acids Res. 15: 9215-9225.

Forrester, W.C., C. Thompson, J.T. Elder, and M. Groudine. 1986. A developmentally stable chromatin structure in the human $\beta$-globin gene cluster. Proc. Natl. Acad. Sci. 83: $1359-1363$.

Forrester, W.C., S. Takegawa, T. Papayannopoulou, G. Stamatoyannopoulos, and M. Groudine. 1987. Evidence for a locus activation region: The formation of developmentally stable hypersensitive sites in globin-expressing hybrids. Nucleic Acids Res. 15: 10159-10177.

Forrester, W.C., U. Novak, R. Gelinas, and M. Groudine. 1989. Molecular analysis of the human $\beta$-globin locus activation region. Proc. Natl. Acad. Sci. 86: 5439-5443.

Greaves, D.R., P. Fraser, M.A. Vidal, M.J. Hedges, D. Ropers, L. Luzzatto, and F. Grosveld. 1990. A transgenic mouse model of sickle cell disorder. Nature 343: 183-186.

Gross, D.S. and W.T. Garrard. 1988. Nuclease hypersensitive sites in chromatin. Annu. Rev. Biochem. 57: 159-197.

Grosveld, F., G. Blom Van Assendelft, D.R. Greaves, and G. Kollias. 1987. Position-independent, high-level expression of the human $\beta$-globin gene in transgenic mice. Cell 51: $975-985$.

Hanscombe, O., M. Vidal, J. Kaeda, L. Luzzatto, D.R. Greaves, and F. Grosveld. 1989. High-level, erythroid-specific expression of the human $\alpha$-globin gene in transgenic mice and the production of human hemoglobin in murine erythrocytes. Genes Dev. 3: 1572-1581.

Harris, P.C., N.J. Barton, D.R. Higgs, S.T. Reeders, and A.O.M. Wilkie. 1990. A long range restriction map between the $\alpha$ globin complex and a marker closely linked to the polycystic kidney disease I (PKDI) locus. Genomics 7: 195-206.

Hatton, C., A.O.M. Wilkie, H.C. Drysdale, W.G. Wood, M.A. Vickers, J. Sharpe, H. Ayyub, I.-M. Pretorius, V.J. Buckle, and D.R. Higgs. 1990. Alpha thalassemia caused by a large $162 \mathrm{~kb})$ deletion upstream of the human $\alpha$-globin gene cluster. Blood 76: 221-227.

Higgs, D.R., M.A. Vickers, A.O.M. Wilkie, I.M. Pretorius, A.P. Jarman, and D.J. Weatherall. 1989. A review of the molecular genetics of the human $\alpha$-globin gene cluster. Blood 73: $1081-1104$.

Holmquist, G.P. 1987. Role of replication time in the control of tissue-specific gene expression. Am. I. Human Genet. 40: $151-173$.

Huisman, T.H.J. and J.H.P. Jonxis. 1977. The Hemoglobinopathies. Marcel Dekker, New York, Basel.

Humphries, R.K., T. Ley, P. Turner, A.D. Moulton, and A.W. Nienhuis. 1982. Differences in human $\alpha-, \beta$ - and $\delta$-globin gene expression in monkey kidney cells. Cell 30: 173-183.

Jarman, A.P. and D.R. Higgs. 1988. Nuclear scaffold attachment sites in the human globin gene complexes. EMBO $I$. 7: 3337-3344.

Karlsson, S. and A.W. Nienhuis. 1985. Developmental regulation of human globin genes. Annu. Rev. Biochem. 54: 1071-1108.

Kollias, G., N. Wrighton, J. Hurst, and F. Grosveld. 1986. Regulated expression of human ${ }^{A} \gamma-, \beta-$, and hybrid $\gamma \beta$-globin genes in transgenic mice: Manipulation of the developmental expression patterns. Cell 46: 89-94.

Krieg, P.A. and D.A. Melton. 1984. Functional messenger RNAs are produced by SP6 in vitro transcription of cloned cDNAs. Nucleic Acids Res. 12: 7057.

Lau, Y.F. and Y.W. Kan. 1983. Versatile cosmid vectors for the isolation, expression, and rescue of gene sequences: Studies with the human $\alpha$-globin gene cluster. Proc. Natl. Acad. Sci. 80: $5225-5229$.

Lauer, J., C.-K.J. Shen, and T. Maniatis. 1980. The chromosomal arrangement of human $\alpha$-like globin genes: Sequence homology and $\alpha$-globin gene deletions. Cell 20: 119-130.

Leibovitz, A., W.B. McCombs, D. Johnston, C.E. McCoy, and J.C. Stinson. 1973. Brief communication: New human cancer cell culture lines. I. SW-13, small-cell carcinoma of the adrenal cortex. I. Natl. Cancer Inst. 51: 691-697.

Lowy, I., A. Pellicer, J.F. Jackson, G.K. Sim, S. Silverstein, and R. Axel. 1980. Isolation of transforming DNA: Cloning the hamster aprt gene. Cell 22: 817-823.

Magram, J., K. Chada, and F. Costantini. 1985. Developmental regulation of a cloned adult $\beta$-globin gene in transgenic mice. Nature 315: 338-340.

Maniatis, T., E.F. Frisch, and J. Sambrook. 1982. Molecular cloning: A laboratory manual. Cold Spring Harbor Laboratory Press, Cold Spring Harbor, New York.

Marks, P.A., M. Sheffery, and R.A. Rifkind. 1987. Induction of transformed cells to terminal differentiation and the modulation of gene expression. Cancer Res. 47: 659-666.

McCormick, D., I. Wallace, J. Kirk, S. Dinsmore, and I. Allen. 1983. The establishment and characterization of a cell line and mouse xenografts from a human malignant melanoma. J. Exp. Pathol. 64: 103-115.

Mellon, P., V. Parker, Y. Gluzman, and T. Maniatis. 1981. Identification of DNA sequences required for transcription of the human al-globin gene in a new SV40 host-vector system. Cell 27: 279-288.

Melton, D.A., P.A. Krieg, M.R. Rebagliati, T. Maniatis, K. Zinn, and M.R. Green. 1984. Efficient in vitro synthesis of biologically active RNA and RNA hybridization probes from plasmids containing a bacteriophage SP6 promoter. Nucleic Acids Res. 12: 7035.

Murphy, D. and J. Hanson. 1987. The production of transgenic mice by the microinjection of cloned DNA into fertilized one-cell eggs. In DNA cloning-A practical approach. (ed. D.M. Glover), vol. 3, pp. 213-247. IRL Press, London.

Nicholls, R.D., N. Fischel-Ghodsian, and D.R. Higgs. 1987. Recombination at the human $\alpha$-globin gene cluster: Sequence features and topological constraints. Cell 49: 369-378.

Old, J.M. and D.R. Higgs. 1983. Gene analysis. Methods in hematology, Vol. 6. In The thalassemias (ed. D.J. Weatherall), pp. 74-102. Churchill, Livingstone, Edinburgh.

Palmiter, R.D. and R.L. Brinster. 1986. Germline transformation of mice. Annu. Rev. Genet. 20: 465-499.

Papayannopoulou, T., N. Brice, and G. Stamatoyannopoulos. 1986. Analysis of human hemoglobin switching in MEL $\times$ human fetal erythroid cell hybrids. Cell 46: 469476.

Rutherford, T.R., J.B. Clegg, and D.J. Weatherall. 1979. K562 human leukaemic cells synthesise embryonic haemoglobin in response of haemin. Nature 280: 164-165.

Ryan, T.M., R.R. Behringer, T.M. Townes, R.D. Palmiter, and R.L. Brinster. 1989a. High-level erythroid expression of human $\alpha$-globin genes in transgenic mice. Proc. Natl. Acad. Sci. 86: $37-41$.

Ryan, T.M., R.R. Behringer, N.C. Martin, T.M. Townes, R.D. Palmiter, and R.L. Brinster. 1989b. A single erythroid-spe- 
cific DNase I super-hypersensitive site activates high levels of human $\beta$-globin gene expression in transgenic mice. Genes Dev. 3: 314-323.

Talbot, D., P. Collis, M. Antoniou, M. Vidal, F. Grosveld, and D.R. Greaves. 1989. A dominant control region from the human $\beta$-globin locus conferring integration site-independent gene expression. Nature 338: 352.

Thompson, S., P.L. Stern, M. Webb, F.S. Walsh, W. Engstrom, E.P. Evans, W.-K. Shi, B. Hopkins, and C.F. Graham. 1984. Cloned human teratoma cells differentiate into neuron-like cells and other cell types in retinoic acid. J. Cell Sci. 72: 3764.

Townes, T.M., J.B. Lingrel, H.Y. Chen, R.L. Brinster, and R.D. Palmiter. 1985. Erythroid-specific expression of human $\beta$ globin genes in transgenic mice. EMBO F. 4: 1715-1723.

Treisman, R., M.R. Green, and T. Maniatis. 1983. cis and trans activation of globin gene transcription in transient assays. Proc. Natl. Acad. Sci. 80: 7428-7432.

Tuan, D., W. Solomon, Q. Li, and I.M. London. 1985. The " $\beta$ like-globin" gene domain in human erythroid cells. Proc. Natl. Acad. Sci. 82: 6384-6388.

Tuan, D.Y.H., W.B. Solomon, I.M. London, and D.P. Lee. 1989. An erythroid-specific, developmental-stage-independent enhancer far upstream of the human " $\beta$-like-globin" genes. Proc. Natl. Acad. Sci. 86: 2554-2558.

van der Ploeg, L.H.T. and R.A. Flavell. 1980. DNA methylation in the human $\gamma \delta \beta$-globin locus in erythroid and nonerythroid tissues. Cell 19: 947-958.

Wilkie, A.O.M., J. Lamb, P.C. Harris, R.D. Finney, and D.R. Higgs. 1990. Stabilization of a truncated human chromosome 16 associated with $\alpha$ thalassaemia by telomeric repeat (TTAGGG). Nature (in press).

Winichagoon, P., D.R. Higgs, S.E.Y. Goodbourn, J.B. Clegg, and D.J. Weatherall. 1982. Multiple arrangements of the human embryonic zeta globin genes. Nucleic Acids Res. 10: $5853-$ 5868.

Yagi, M., R. Gelinas, J.T. Elder, M. Peretz, T. Papayannopoulou, G. Stamatoyannopoulos, and M. Groudine. 1986. Chromatin structure and developmental expression of the human $\alpha$-globin cluster. Mol. Cell. Biol. 6: 1108-1116.

Zeitlin, H.C. and D.J. Weatherall. 1983. Selective expression within the human $\alpha$ globin gene complex following chromosome-dependent transfer into diploid mouse erythroleukaemia cells. Mol. Biol. Med. 1: 489-500.

Zinn, K., D. DiMaio, and T. Maniatis. 1983. Identification of two distinct regulatory regions adjacent to the human $\beta$-interferon gene. Cell 34: 865-879. 


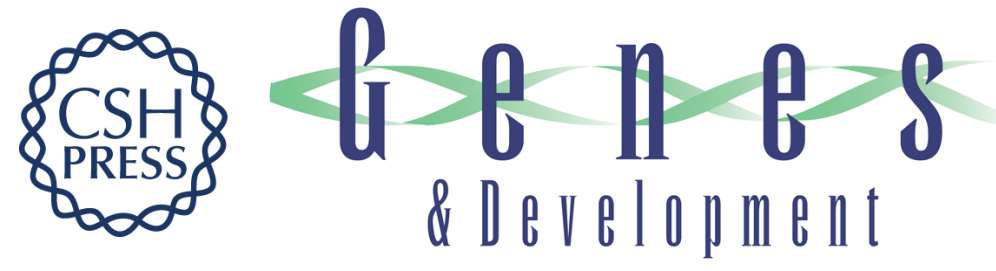

\section{A major positive regulatory region located far upstream of the human alpha-globin gene locus.}

D R Higgs, W G Wood, A P Jarman, et al.

Genes Dev. 1990, 4:

Access the most recent version at doi:10.1101/gad.4.9.1588

References This article cites 59 articles, 21 of which can be accessed free at: http://genesdev.cshlp.org/content/4/9/1588.full.html\#ref-list-1

License

Email Alerting

Service

Receive free email alerts when new articles cite this article - sign up in the box at the top right corner of the article or click here.

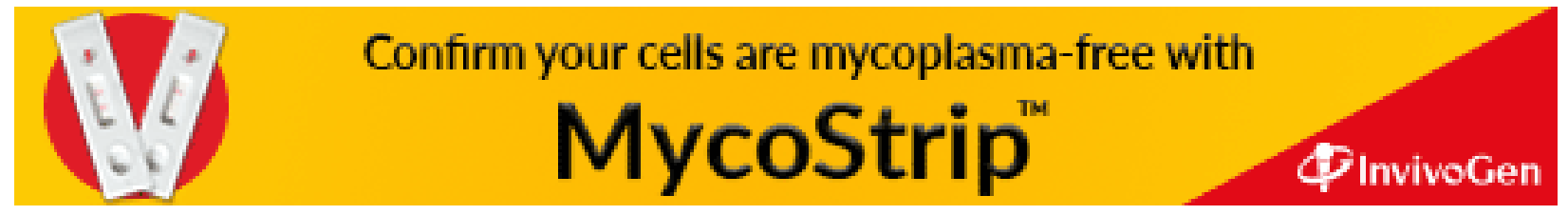

